W.P. Holland

\title{
The Phases of Matter
}

MeditATiONS 11-19.

Nanotechnology Perceptions 7 (2011) 99-140

Nonsubscribers: purchase individual article 